\title{
Regulations of Recognition and Protection on Ulayat Rights of Indigenous Peoples in Indonesia
}

\author{
Fifik Wiryani \\ University of Muhammadiyah Malang \\ fifik@umm.ac.id,fwiryani2016@gmail.com
}

\begin{abstract}
The Ulayat Right of Indigenous People is a constitutional right and is an Indigenous People's Human Rights. The current problem is that there is an inconsistency of constitutional rights regarding Ulayat rights implementation. The inconsistency is in the form of recognition of the Ultimate MHA's Ultimate Rights, Conditional Recognition and Denial / Abandonment of the existence of Ulayat Rights. Therefore, the setting of Ulayat Rights as a constitutional right is contradictory to the constitution due to the absence of legal guarantee on its recognition and protection. This research suggests to achieve harmony among related regulation or to create certain laws that specifically regulates the recognition and protection of the Ulayat Rights of the MHA that meet a fair legal guarantee.
\end{abstract}

Keywords: ulayat rights, recognition, protection, legal certainty, juscice

\section{INTRODUCTION}

Indonesia is the largest archipelago nation in the world which consists of \pm 13487 islands, with its various customs, language, art, culture, and belief. The Indonesia also consists of various Indigenous Peoples (hereinafter referred to as IP) which has grown hundreds or even thousands of years ago [1]. Currently there are 2.302 IP and 70 million citizens distributed in some of Indonesia. The Directorate General of Remote Indigenous Communities of the Ministry of Social Affairs has officially recognized 365 IP [3].

IP according to the Alliance of IP of the Archipelago (AMAN) refers to a community that has a hereditary ancestral origin, living in a certain geographical area, has a distinctive system of values, ideology, economic, political, cultural and social [4]. This IP is the forerunner of the Indonesian nation.

Under the provisions of Article 33 (3) of the 1945 Constitution, Natural resources in Indonesia are controlled by the state to achieve the greatest prosperity of the people. This provision is known as the Ideology of State Rights (ISR). The Constitutional Court in its decision has interpreted the ISR which includes five definitions, namely: beleid, daad, bestuurdaad, beheer daad and toezicht houden daad for the greatest purpose prosperity of the people [5].

Certain geographical areas owned by IP or Ulayat Rights (hereinafter referred to as UR) may be land and/or

\author{
Mokhammad Najih \\ University of Muhammadiyah Malang \\ najihumm17@gmail.com
}

waters, both inland and marine waters. The UR is a very important element in sustaining the life and livelihood of IP [6]. The UR is a natural resource not only as a mere economic object but also as an integral part of its life, such as maintaining historical relationships and spiritual relationships with its natural resources, and the social space and cultural development of IP from generation to generation The UR is natural resource that acts not only as a mere economic object but also as an integral part of its life; it functions to maintain historical and spiritual relations with its natural resources and also to maintain the IP's social space and cultural development from generation to the next [7]. UR is the main natural resource of IP has a big role in maintaining the existence of customary law community because they depend their life on natural resources in their place of residence [8].

The history of land law in Indonesia is closely related to UR [9]. Long before the establishment of the state of Indonesia, IP had known and owned UR. The UR is a fundamental right of IPs which is protected by international law as well as national ones. In International law, this property rights are governed among others in The United Nations Charter 1945; The Universal Declaration of Human Rights 1948; International Covenant on Economic, Social and Cultural Rights; and Rio Declaration on Environtment and Development 1992.

UR is guaranteed by the 1945 Constitution Article $18 \mathrm{~B}(2)$ and $28 \mathrm{I}(3)$. The recognition of $\mathrm{UR}$ is further regulated in various laws in the field of human rights and natural resources. Nurhidayati's research results found that during 1979-2015, there are 124 local legal products that regulate the IP and the rights it holds [9]. However, the legal product is insufficient to protect the rights of IP. As a result, IP until now live in conditions that are less prosperous [2] because of the UR that regardless of IP power due to related regulations Land Rights created by the state.

The facts show that from the 2,302 existing UR in Indonesia [2] there are only 365 URs that are officially recognized by the Ministry of Social. There are only 11 URs that have been recognized and stipulated under the law product of Regional Regulation, and only 1 UR that can proceed the registration [3].

Another fact says that URs claimed as state forest areas and the URs managed productively by third parties. In 2014 , there were $4,050,231.18$ hectares $(81 \%)$ of forest determined by the Ministry of Forestry located within URs [10]. The total area issued by the government is $2,506,498.36$ Hectares $(48 \%)$ and the IP's ownership 
rights managed by the unlicensed third party are 2,756,559.93 Hectares (52\%) [14].

Since the reform era, many IPs in Indonesia demand the return of their URs that have been "stolen" by the Government and Investors either through peaceful means or with mass movement that is colored by violence. The demand for UR restoration movement resulting in horizontal and vertical conflict, and often the IP receive intimidation, expulsion, invasion, and arrest, along with successive shootings, incarceration, burning of IP villages or cultivation or criminalization by the state [1].

The focus of the study which becomes the problem in this paper is how the recognition and protection of URs of IPs in the legislation in Indonesia?

\section{METHOD}

The research method employed in this research is a normative legal research as a means to conceptualize the law as a norm, rule, principle or dogmas, by using statute approach [11]. By way of reviewing regulations on the recognition and protection of IP. The data source is secondary data.

\section{RESULT}

Recognition of Customary Rights of IP in Legislation. Constitutionally, the rights of IP has been regulated in the 1945 Constitution Article 18 B (2) and Article 28 I (3) and various laws and regulations. The problem is that the provisions on the recognition and protection of UR of IP in the legislation are not consistently regulated. Broadly speaking, the recognition and protection of UR can be divided into three classifications, namely: 1) Regulation of recognition and protection; 2) Setting recognition and protection restrictions; and 3) Regulation of IP's Ultimate Conflict Resettlement. The respective classifications of recognition and protection of URs are as follows:

\section{Regulation of Acknowledgment and Protection of \\ URs in Full}

Table 1. Regulatory of Restricting Acknowledgment and Protection of UR

\begin{tabular}{|c|c|c|c|c|c|c|c|c|}
\hline REGULATORY RESTRICTIONS UR & A & $\mathrm{B}$ & $\mathrm{C}$ & $\mathrm{D}$ & $\mathrm{E}$ & $\mathrm{F}$ & $\mathrm{G}$ & $\mathrm{H}$ \\
\hline as long as it is alive & $\sqrt{ }$ & $x$ & $\sqrt{ }$ & $x$ & $\sqrt{ }$ & $\sqrt{ }$ & $\sqrt{ }$ & $\sqrt{ }$ \\
\hline $\begin{array}{l}\text { in harmony with the development of society, times \& } \\
\text { civilizations }\end{array}$ & $\sqrt{ }$ & $\sqrt{ }$ & $x$ & $\sqrt{ }$ & $x$ & $x$ & $\sqrt{ }$ & $x$ \\
\hline $\begin{array}{l}\text { in accordance with the principle of the Unitary State of the } \\
\text { Republic of Indonesia (NKRI) }\end{array}$ & $\sqrt{ }$ & $x$ & $x$ & $\times$ & $x$ & $x$ & $\sqrt{ }$ & $x$ \\
\hline based on the unity of the nation & $\times$ & $x$ & $\sqrt{ }$ & $\times$ & $x$ & $\times$ & $x$ & $x$ \\
\hline in accordance with the national and State interests & $x$ & $x$ & $\sqrt{ }$ & $x$ & $\sqrt{ }$ & $x$ & $x$ & $\sqrt{ }$ \\
\hline does not conflict with other laws and other regulations & $x$ & $x$ & $\sqrt{ }$ & $\times$ & $x$ & $x$ & $x$ & $\sqrt{ }$ \\
\hline Its existence has been confirmed by regional regulations & $x$ & $x$ & $x$ & $x$ & $\sqrt{ }$ & $x$ & $x$ & $\sqrt{ }$ \\
\hline
\end{tabular}

Source: Data processed from the 1945 Constitution; MPR Decree No.XVII/MPR/1998; Act 5/1960; Act 39/1999; Act 41/1999; Act 2/2002; Act 24/2003; Act 7/2004.

\section{Explanation:}

$\mathrm{A}=$ the 1945 Constitution

$\mathrm{B}=$ MPR Decree No. XVII / MPR / 1998

$\mathrm{C}=$ Act Number 5 Year 1960

$\mathrm{D}=$ Act Number 39 Year 1999
Acknowledgment and protection of UR are fully regulated in: MPR Decree Number IX/MPR/2001; Act no. 22 of 2001; Act Number 27 the Year 2003; Act Number 38 the Year 2004; Act Number 27 the Year 2007; and Act no. 39 the Year 2014.

a. Agrarian reform and natural resource management shall be carried out in accordance with the principles of recognize, respect, and protect the rights of IPs and tribal peoples' cultural diversity of agrarian resources; [12]

b. Oil and Gas Cooperation Contracts are required to develop the local communities and guarantee the rights of IPs [13]

c. Geothermal Mining Business Activities is not allowed to conduct at funerals, sacred places, public places, public facilities and infrastructure, nature reserves, cultural heritage, and UR [14].

d. Land owner/user of state land/IP Owners of UR, whose land is needed for road construction, are entitled to compensation [15].

e. Plantation Businesses requires UR to consult with the IP as its owners to obtain agreement on the land and the compensation [16].

f. The granting of a Coastal Water Concession Rights shall recognize, respect, and protect the rights of IP and/local Communities [17].

g. The regulation of Ur's recognition and protection as a whole has provided a fair guarantee on IP's legal certainty as a part of Human Rights; this also allows IP to use and/or utilize its UR. The guarantee of legal certainty fairly in harmony with human rights as stipulated in the 1945 Constitution Article 28 D (1).

2. Restricting Acknowledgment and Protection of UR

The purpose of Restricting the Recognition and Protection of UR is the existence of a number of conditions that must be met before the MHA's Ultimate Rights are recognized and protected.
$\mathrm{E}=$ Act Number 41 Year 1999
$\mathrm{~F}=$ Act Number 2 Year 2002
$\mathrm{G}=$ Act Number 24 Year 2003
$\mathrm{H}=$ Act Number 7 Year 2004 
The Arrangements of the Restriction on the Recognition and Protection of UR are regulated in the 1945 Constitution Article 18.B.(2) and 28.I.(3); Decree of MPR XVII/MPR/1998 Article 41; Act 5/1960 Article 2.(4) and 3; Act 39/1999 Article 6.(1) and (2); Act 41/1999 Article 4.(3) and 5.(4); Act 2/2002 Article 35.(6); Act 24/2003 Article 51.(1); Act 7/2004 Article 6.(2) and (3).

The articles regulating the recognition and protection of UR, it can be inventoried that the recognition and protection of UR there are seven types of requirements. Each of the restrictions on the recognition and protection of UR on Table 1.

The requirements for the recognition and protection of UR regulated in the respective laws and regulations are not the same in each sector. This does not provide a fair guarantee of legal certainty for IPs to the ownership of their URs as part of IPs Ownership Rights which implies no legal protection for IPs to use and/or utilize UR, as mandated by the 1945 Constitution Article 28D(1).

3. Regulation of UR's Ultimate Conflict Resettlement

The denial of MHA's UR is regulated in: Act 5/1990 Article 9.(2); Act 41/1999 Article 1.4, 6, 5.(1) and (2); Act 26/2007 Article 1.33, 7.(3) and 60; Act 23/2014 Article 13, 14.(1), 15.(2); Appendix of Act 23/2014; and Government Regulation 24/1997 Article 9.(1). Based on the regulation, found the provisions of the denial of UR, namely:

a. Determination of specific area as a life support system protection area made unilaterally by the government without considering the existence of UR preexisting IP [18];

b. Act 41/1999 expressly provide that UR of forest is a state forest that UR is not recognized as belonging to the IP. Based on the Constitutional Court Decision Number 35/PUU-X/2012, the Constitutional Court has corrected the perspective on UR in the form of forest as state forest is returned to IP's Forests [19];

c. Act $26 / 2007$, IP is not included in the definition of people whose rights are respected in the implementation of spatial and not include a right to: know the layout plan; enjoy the value of space as a result of spatial planning; obtaining appropriate reimbursement for losses arising from the implementation of development activities; filed an objection to the competent authority over development; to file demands for cancellation of permits and cessation of development; and to file a lawsuit against the government and/or the permit holder if development activities not in accordance with the spatial plan cause losses [20].

d. UR Territories cover land and waters. For IP having UR in the form of marine waters, the provisions of Appendix letters Y Act 23/2014 [21].

e. Object of land registration contained in Government Regulation 24/1997 does not include UR. So there is evidence of land ownership, then it is unlikely that IP will have any proof of ownership of UR [22].
The denial of the UR does not provide a fair legal certainty [23] for IP as part of its Human Rights and does not provide a legal protection guarantee for IP to use and/or utilize UR. The absence of a guarantee of legal certainty is justly contrary to human rights as regulated in the 1945 Constitution Article 28D(1).

\section{CONCLUSION}

The provisions on the recognition and protection of UR of IP in various laws and regulations are varied, ie there is a regulation of the recognition and protection of the Ultimate Rights of IP as a whole; recognition and protection provided after several conditions are met; and denial of the existence of UR. The inconsistency of the recognition and protection of UR implies a fair legal uncertainty and equal treatment before the law as mandated by the 1945 Constitution Article 28.D.(1).

Based on the findings of inconsistencies in the recognition and protection of UR, it is necessary to harmonize all sectoral laws that have implications for the existence of UR so as to provide a fair legal certainty guarantee and equal treatment before the law based on the 1945 Constitution. Alternative the other is to create laws that specifically regulate the recognition and protection of $\mathrm{MHA}$ rights as the order of the Constitutional Court.

\section{REFERENCES}

[1] Besse Sugiswati, "Perlindungan Hukum Terhadap Eksistensi Masyarakat Adat di Indonesia"; Jurnal Perspektif, Volume XVII No. 1 Tahun 2012 Edisi Januari

[2] Nurhidayati, Pengakuan dan Perlindungan hak-Hak masyarakat Adat Dari Perspektif Hukum Nasional, Procceding KNIT-2 Nusa Mandiri 346-352, ISBN: 978-602-72850-1-9.

[3] Direktur Tata Ruang dan Pertanahan BAPPENAS, Kebijakan Nasional Penetapan Tanah Adat/Ulayat, Makalah disampaikan pada Lokakarya Realisasi Hak Atas Tanah dan Rumah di Daerah Tertinggal, Kerjasama Bappenas dengan UN Habitat, Jakarta: 15 Januari 2014.

[4] ICRAF, LATIN dan P3AE-UI, Seri Kebijakan I: Kajian Kebijakan Hak-Hak Masyarakat Adat di Indonesia; Suatu Refleksi Pengaturan Kebijakan Dalam Era Otonomi Daerah, 2001.

[5] http://www.hukumonline.com/berita/baca/ hol18835/mk-hapus-frase-di-mukasekaligus-; accessed on 25-05-2011;

[6] Ratna Artha Windari, "Keberpihakan Regulasi Pertanahan Terhadap Hak Masyarakat Adat (Studi Kasus Sengketa Tanah Adat Di Desa Kubutambahan, Kabupaten Buleleng; Jurnal Ilmu Sosial dan Humaniora, Vol. 3, No. 1, April 2014.

[7] Fifik Wiryani, Reformasi Hak Ulayat, Malang: Setara Press, 2009.

[8] Muazzin, "Hak masyarakat Adat (Indigenous Peoples) Atas Sumber Daya Alam: Perspektif 
Hukum Internasional”, Padjadjaran Jurnal Ilmu Hukum, Volume 1-No 2- Tahun 2014.

[9] Rosalina, "Eksistensi Hak Ulayat Di Indonesia", Jurnal Sasi, Vol.16. No.3 Bulan Juli - September 2010.

[10] Dyah Ayu Widowati, dkk, Pengakuan dan Perlindungan Hak Atas Tanah Masyarakat Hukum Adat di Kawasan Hutan, Yogyakarta: STPN Press, 2014.

[11] Peter Mahmud Marzuki, Penelitian Hukum; Jakarta: Kencana Prenada Media Group, 2005.

[12] Tap MPR Nomor IX/MPR/2001 Pasal 4 huruf j Tap MPR Nomor IX/MPR/2001 Pasal 4 huruf j.

[13] UU No. 22 Tahun 2001 Pasal 11 ayat (3) huruf p UU No. 22 Tahun 2001 Pasal 11 ayat (3) huruf p.

[14] UU Nomor 27 Tahun 2003 Pasal 16 ayat (3) huruf a.

[15] UU Nomor 38 Tahun 2004 Pasal 58 ayat (3) UU Nomor 38 Tahun 2004 Pasal 58 ayat (3).

[16] UU No. 39 Tahun 2014 Pasal 12 ayat (1) dan (2) dan Pasal 13.
[17] UU Nomor 27 Tahun 2007 Pasal 21 ayat (4) huruf b.

[18] Act Number 5 on 1990 Article 9 (2).

[19] Maria Rita Roewiastoeti, "Dampak Sosial Politik Putusan Mahkamah Konstitusi Nomor 35/PUUX/2012"; Wacana Jurnal Transformasi Sosial; Nomor 33 Tahun XVI, 2014.

[20] Act Number 26 on 2007 Articles: 1.33, 7 (3) and 60.

[21] Act Number 23 on 2014 Articles: 13, 14 (1), 15 (2) and Appendix Act Number 23 on 2014

[22] PP Nomor 24 Tahun 1997 Pasal 9 ayat (1).

[23] Noer Fauzi Rachman, "Masyarakat Hukum Adat Adalah Bukan Penyandang Hak, Bukan Subyek Hukum, dan Bukan Pemilik Wilayah Adatnya", Wacana Jurnal Transformasi Sosial; Nomor 33 tahun XVI, hlm. 25. 